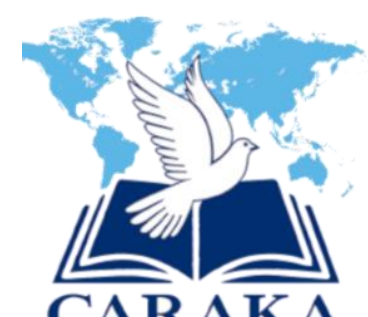

\title{
Tinjauan Etika Kristen Tentang Praktek Penggelembungan Dana (Mark-Up) Bagi Pebisnis Kristen
}

\author{
Yosua Sibarani \\ Sekolah Tinggi Teologi Happy Family \\ yosuasibarani@stthf.ac.id
}

\begin{abstract}
In the realities of everyday life, Christians often encounter various kinds of temptations to do things that are hated by God. Of the many temptations, dishonesty has become a struggle for all Christians, including Christian businessmen. This form of dishonesty is inflating funds or often known as mark-up. This paper discusses the practice of mark-up and how Christian businessmen react to it from a Christian ethical perspective. A Christian businessman should glorify God through his business activities by rejecting behavior that is contrary to Christian faith. As a follower of Christ, he must have a different attitude from society in general. The Bible as the word of God is the basis for studying the practice of inflating these funds so that Christian businessmen can apply it in their life in general and their business activities in particular.
\end{abstract}

Keywords: Inflating of Funds; Mark-up; Christian Businessman; Christian Ethics

\begin{abstract}
Abstrak
Dalam kenyataan hidup sehari-hari, tidak jarang orang Kristen berhadapan dengan berbagai macam godaan berbuat hal yang dibenci oleh Allah. Dari sekian banyak godaan, ketidakjujuran menjadi pergumulan semua kalangan Kristen, termasuk pebisnis Kristen. Bentuk ketidakjujuran tersebut adalah penggelembungan dana atau sering dikenal dengan istilah mark-up. Tulisan ini membahas tentang praktek penggelembungan dana (mark-up) dan cara pebisnis Kristen menyikapinya berdasarkan perspektif etika Kristen. Seorang pebisnis Kristen seharusnya memuliakan Allah melalui aktivitas bisnis yang dilakukannya dengan menolak perilaku yang bertentangan dengan iman Kristen. Sebagai pengikut Kristus, ia harus memiliki sikap yang berbeda dengan masyarakat pada umumnya. Alkitab sebagai firman Allah menjadi landasan untuk mengkaji praktek penggelembungan dana tersebut sehingga pebisnis Kristen dapat menerapkannya dalam hidupnya secara umum dan aktivitas bisnisnya secara khusus.
\end{abstract}

Kata Kunci: Penggelembungan Dana; Mark-up; Pebisnis Kristen; Etika Kristen 


\section{PENDAHULUAN}

Dalam kehidupan sehari-hari banyak dijumpai ketidakjujuran. Ketidakjujuran ini biasanya disebabkan oleh adanya godaan untuk melakukannya. Jenny Teichman mengungkapkan bahwa ada banyak godaan dalam kegiatan kehidupan sehari-hari. Dalam penjelasannya, dia juga memberikan contoh godaan yang terjadi seperti godaan untuk memanipulasi hasil demi memperoleh nama baik, apresiasi atau uang. Ada juga godaan untuk menjiplak karya orang lain yang dikenal dengan plagiarisme. Selain itu, terdapat juga godaan bagi para penyunting majalah ilmiah untuk mengabaikan makalah-makalah dan hasil riset-riset yang dibuat orang-orang yang dianggap kurang penting untuk mempublikasikan pemikiran orang-orang yang berkuasa. ${ }^{1}$

Di Indonesia, praktek ketidakjujuran rentan terjadi. Salah satu bentuk ketidakjujuran tersebut adalah praktek penggelembungan anggaran (mark-up) dari oknum-oknum tertentu. Pada tahun 2019, Bursa Efek Indonesia menemukan adanya penggelembungan dana oleh PT TPS Food terkait Hasil Investigasi Berbasis Fakta PT Ernst \& Young Indonesia $(E Y) .^{2}$ Tumpak Hatorangan Panggabean yang menjabat sebagai Pelaksana Tugas Pimpinan KPK pada tahun 2009 pernah mengatakan bahwa 35 persen anggaran negara berpotensi dirugikan dari pengadaan barang dan jasa lewat praktek mark-up. ${ }^{3}$ Temuan itu memang belum sampai pada kesimpulan ada unsur korupsi. Namun, sudah menjadi rahasia umum bahwa proyek pengadaan barang dan jasa merupakan lahan subur korupsi di Indonesia. ${ }^{4}$ Analisis kecenderungan korupsi sepanjang tahun 2018 yang dilakukan oleh Indonesian Corruption Watch (ICW) memperlihatkan kasus korupsi bermoduskan penggelembungan anggaran dan penyalahgunaan anggaran menempati urutan teratas. ${ }^{5}$ Penggelembungan anggaran dilakukan secara sistematis dan melibatkan banyak orang yang bermuara pada KKN. ${ }^{6}$

Di dalam dunia bisnis, pengambilan keuntungan yang besar adalah hal yang wajar. A. Sonny Keraf mengatakan bahwa pada umumnya seorang pebisnis memiliki motivasi dasar yaitu untuk mencari keuntungan dan memperoleh tingkat hidup yang mencukupi secara

${ }^{1}$ Jenny Teichman, Etika Sosial (Yogyakarta: Kanisius, 2003), 126.

2 "Ada Penggelembungan Dana, BEI Akan Panggil Direksi AISA," accessed November 16, 2020, https://www.cnbcindonesia.com/market/20190327124001-17-63171/ada-penggelembungan-dana-bei-akanpanggil-direksi-aisa.

3 "Korupsi Pengadaan Barang Terbanyak, Mark Up," accessed November 16, 2020, https://www.viva.co.id/korupsi/110936-korupsi-pengadaan-barang-terbanyak-mark-up.

4 "Direktorat Jenderal Anggaran," accessed November 16, 2020, http://anggaran.kemenkeu.go.id/in/post/penggelembungan-anggaran-modus-laten-korupsi.

5 "ICW: Mark Up Dan Penyalahgunaan Anggaran Modus Korupsi Paling Banyak Di 2018," accessed November 16, 2020, https://nasional.kompas.com/read/2019/02/08/11491331/icw-mark-up-dan-penyalahgunaananggaran-modus-korupsi-paling-banyak-di-2018.

${ }^{6}$ I Kadek Edy Sanjaya, I Nyoman Gede Sugiartha, and Ida Ayu Putu Widiati, "Pertanggungjawaban Pidana Pelaku Tindak Pidana Korupsi Dana Hibah Pengadaan Bibit Sapi (Studi Putusan Nomor 1/PID.SUSTPK/2019/PN DPS)," Jurnal Preferensi Hukum 1, no. 1 (2020): 39. 
material. ${ }^{7}$ Namun hal itu dapat mendorong terjadinya ketidakjujuran penentuan harga barang atau jasa. Seorang pebisnis Kristen seharusnya memiliki motivasi yang mulia dalam melakukan bisnisnya sebagaimana yang diajarkan oleh Alkitab. Lebih lanjut, Larry Burkett menyebutkan bahwa bisnis Kristen seharusnya dilakukan untuk melayani Tuhan untuk kemuliaan-Nya (Kol. 3:23). ${ }^{8}$ Daniel Ronda berpendapat bahwa keuntungan hendaknya tidak dijadikan sebagai tujuan satu-satunya dalam bisnis supaya seseorang tidak berupaya menghalalkan segala cara untuk mencapai keuntungan. ${ }^{9}$ Untuk itu, praktek penggelembungan dana perlu dikaji berdasarkan sudut pandang etika bisnis Kristen untuk menjadi pedoman bagi pelaku bisnis Kristen yang memuliakan nama Tuhan.

Berdasarkan permasalahan di atas, maka penulis akan mendeskripsikan pandangan etika bisnis Kristen terhadap praktek mark-up tersebut sebagai pedoman dan refleksi bagi pebisnis Kristen supaya terhindar dari praktek mark-up tersebut. Dengan demikian, orang Kristen diharapkan bertindak dengan bijaksana dalam melakukan apa saja yang menjadi panggilan hidup mereka.

\section{METODE PENELITIAN}

Penelitian ini menggunakan metode kualitatif deskriptif dengan pendekatan studi literatur/pustaka. Penelitian kualitatif ini memungkinkan adanya penemuan teori baru yang tentunya akan diuji dan diverifikasi dengan metode kuantitatif yang bersifat empiris. ${ }^{10}$ Penulis mencari, mengelompokkan, dan menyajikan data berupa informasi tentang penggelembungan dana secara umum maupun secara khusus yang dilakukan oleh orang Kristen. Untuk itu, penulis menggunakan berbagai literatur seperti jurnal, buku, media daring, maupun terbitan lainnya yang relevan dengan penelitian ini.

\section{HASIL DAN PEMBAHASAN}

\section{Etika Bisnis Kristen}

Secara etimologis, kata "etika" berasal dari kata Yunani, yaitu "ethos". Kata "ethos" memiliki arti kebiasaan atau adat. ${ }^{11}$ Etika tidak hanya menyinggung perbuatan-perbuatan lahir saja, tetapi juga menyinggung secara mendalam kaidah-kaidah maupun motif-motif seseorang melakukan perbuatan. ${ }^{12}$ Menurut Daniel Ronda, etika bukanlah suatu pengertian deskriptif yang hanya menjelaskan suatu fenomena, melainkan juga memberikan penilaian tentang salah

\footnotetext{
${ }^{7}$ A. Sonny Keraf, Etika Bisnis (Yogyakarta: Kanisius, 2000), 81.

${ }^{8}$ Larry Burkett, Kunci Sukses Bisnis Menurut Alkitab (Yogyakarta: Andi Offset, 1997), 12.

${ }^{9}$ Daniel Ronda, Leadership Wisdom (Bandung: Kalam Hidup, 2011), 83.

${ }^{10}$ Hengki Wijaya, "Metode Penelitian Pendidikan Teologi" (2013).

${ }^{11}$ J. Verkuyl, Etika Kristen Bagian Umum (Jakarta: BPK Gunung Mulia, 2009), 1.

${ }^{12}$ Ibid.
} 
dan benar, baik dan jahat. ${ }^{13}$ Senada dengan itu, Malik Bambangan berpendapat bahwa etika juga merupakan pembicaraan tentang boleh atau tidaknya sesuatu dilakukan oleh manusia, selain benar atau salah. ${ }^{14}$ Dengan kata lain, etika berkaitan dengan apa yang secara moral benar dan salah. ${ }^{15}$ Berdasarkan pendapat di atas, maka etika Kristen secara sederhana adalah suatu cabang ilmu teologi yang memanukan masalah tentang apa yang baik dari sudut pandang kekristenan.

Etika Kristen bersumber dari kepercayaan kepada Allah yang menyatakan dirinya di dalam Yesus Kristus. Menurut Schilder, etika Kristen adalah ilmu teologi yang menyelidiki ukuran-ukuran yang tetap, masyarakat yang berganti-ganti dan kewajiban manusia untuk menentukan kehendaknya taat dalam situasi kondisi yang aktual dan konkret terhadap kehendak Allah yang dinyatakan. Norman L. Geisler mengungkapkan ciri-ciri etika Kristen sebagai berikut: ${ }^{16}$ (1) Etika Kristen berdasarkan kehendak Allah (Im. 11:45; Mat. 5:48; Ibr. 6:18). (2) Etika Kristen bersifat mutlak (Mal. 3:6; Yak. 1:17). (3) Etika Kristen berdasarkan penyataan Allah (Rm. 1:19-20; 2:12-15; 2:18; 3:2). (4) Etika Kristen bersifat menentukan (preskriptif). Etika Kristen pada dasarnya adalah preskriptif, bukan deskriptif. Karena etika Kristen berkenaan dengan apa yang seharusnya dilakukan, bukan apa yang sedang dilakuan (deskriptif). (5) Etika Kristen itu deontologis atau berpusat kepada kewajiban seseorang sebagai orang Kristen. Alexander Hill mengatakan bahwa etika Kristen adalah penerapan nilai-nilai Kristiani terhadap proses pengambilan keputusan. ${ }^{17}$ Lebih lanjut, ia menambahkan bahwa etika Kristen ini berlaku di setiap segi kehidupan orang percaya, termasuk bisnis.

Etika bisnis merupakan studi yang dikhususkan mengenai moral yang benar dan salah yang berkonsentrasi pada standar moral sebagaimana diterapkan dalam kebijakan, institusi, dan perilaku bisnis. ${ }^{18}$ Istilah bisnis berarti "usaha komersial (menghasilkan keuntungan) dalam dunia perdagangan", "bidang usaha”, atau "usaha dagang". ${ }^{19}$ Sehingga bisnis adalah suatu usaha yang dilakukan oleh seseorang, kelompok orang atau organisasi untuk mendapatkan keuntungan dari penawaran barang dan jasa. ${ }^{20}$ Berdasarkan pengertian tersebut, bisnis yang dilakukan oleh pebisnis Kristen pun tetap memberikan keuntungan bagi pelakunya karena apabila sebaliknya, hal tersebut bukanlah bisnis.

\footnotetext{
${ }^{13}$ Ronda, 88.

${ }^{14}$ Malik Bambangan, "Perspektif Teologis Terhadap Etika Bisnis Kristen," Jurnal Luxnos 5, no. 2 (2019): 135.

${ }^{15}$ Norman L. Geisler, Etika Kristen: Pilihan Dan Isu Kontemporer (Malang: Literatur SAAT, 2010), 13.

16 Ibid.

${ }^{17}$ Alexander Hill, Bisnis Yang Benar (Bandung: Kalam Hidup, 2001), 10.

${ }_{18}$ Bambangan,_136.

19 "Hasil Pencarian - KBBI Daring," accessed January 29, 2021, https://kbbi.kemdikbud.go.id/entri/bisnis.
20 Jacky Latupeirissa, "Etika Bisnis Ditinjau Dari Perspektif Alkitab," PASCA : Jurnal Teologi dan Pendidikan Agama Kristen 15, no. 1 (2019): 15.
} 
Etika bisnis Kristen berada di bawah payung etika Kristen, karena etika bisnis Kristen merupakan salah satu bagian praktis dari etika Kristen. Secara sederhana yang dimaksud dengan etika bisnis Kristen adalah cara-cara untuk melakukan kegiatan bisnis, yang mencakup seluruh aspek yang berkaitan dengan individu, organisasi/perusahaan, industri dan juga masyarakat yang berlandaskan Alkitab sebagai firman Tuhan. Definisi ini mencakup bagaimana seorang pelaku bisnis menjalankan bisnis secara adil, jujur, sesuai dengan prinsip firman Tuhan. Firman Tuhan berkata, "Siapa loba akan keuntungan gelap, mengacaukan rumah tangganya, tetapi siapa membenci suap akan hidup." (Ams. 15:27). Tuhan memberikan ketetapan bahwa pebisnis Kristen tidak diperkenankan rakus terhadap keuntungan, apalagi dengan perbuatan curang (keuntungan gelap) dan suap.

\section{Penggelembungan Dana (Mark-up)}

Pada dasarnya, istilah "mark-up" dipakai dalam ilmu ekonomi yaitu penetapan harga barang atau jasa. Namun, istilah ini telah berubah makna yaitu, menaikkan harga barang atau jasa untuk kepentingan pribadi. Untuk itu, penulis akan menjelaskan terlebih dahulu pengertian mark-up dan praktek mark-up dari awal hingga perkembangannya saat ini. Istilah "mark-up" adalah istilah yang dipakai dalam ilmu ekonomi ataupun bisnis, yaitu selisih antara harga barang atau jasa dengan harga jualnya. Mark-up ini ditambahkan kepada sebuah produk untuk menghasilkan profit atau keuntungan. Jack Ingels menjelaskan arti mark-up: "Markup is the difference between the cost of a good or service and its selling price." contoh, pedagang yang membeli barang-barang dagangan akan menentukan harga jualnya setelah menambah harga beli dengan sejumlah mark-up. Perhatikan formula di bawah ini.

\section{HARGA BELI + MARK-UP = HARGA JUAL}

Jadi, mark-up ini merupakan kelebihan harga jual di atas harga belinya atau jumlah harga yang ditambahkan pada biaya untuk menentukan harga. ${ }^{22}$ Keuntungan bisa diperoleh dari sebagian mark-up tersebut. Selain itu, pedagang tersebut juga harus mengeluarkan sejumlah biaya eksploitasi yang juga diambilkan dari sebagian mark-up. ${ }^{23}$

Namun akhirnya, istilah "mark-up" menjadi berkonotasi negatif. Mark-up dalam dunia bisnis diartikan sebagai penggelembungan anggaran. Metode penghitungannya pun beragam. Sistem selisih harga ini diterapkan banyak orang pula pada bentuk korupsi kecil-

${ }^{21}$ Jack Ingels, Ornamental Horticulture: Science, Operations, and Management (Boston: Cengange Learning, 2009), 601.

22 “Apa Itu Mark up? Pengertian Mark up Dan Definisinya Dalam Kamus Ekonomi \& Bisnis,” accessed November 16, 2020, https://glosarium.org/arti-mark-up-di-ekonomi/.

${ }^{23}$ Basu Swastha, Azas-Azas Marketing (Yogyakarta: Liberty, 2002), 10. 
kecilan sampai besar-besaran, sehingga kata mark-up itu melekat kepada sebuah pengertian negatif. Yang pasti, hal seperti ini bukanlah bentuk penipuan baru. Kasus terbesar menyeret para koruptor adalah penyalahgunaan wewenang (a buse of power) dalam melipatgandakan pembiayaan atas kebutuhan dengan cara ilegal. Dalam pengertian konotasi negatif, markup secara sederhana adalah manipulasi, berbohong, curang atau menipu. ${ }^{24}$

Ada beberapa cara yang dapat dilakukan untuk melakukan mark-up, mulai dari perorangan sampai kelompok. Praktek mark-up dapat dilakukan dengan cara sebagai berikut: Pertama, meminta nota atau faktur tidak sesuai harga.Cara ini dilakukan oleh pembeli dengan meminta penjual menuliskan jumlah harga yang lebih tinggi dari harga yang sudah disepakati sebelumnya. Sebagai contoh, harga kesepakatan suatu barang adalah Rp. 150.000,-. Lalu pembeli meminta penjual menuliskan Rp. 200.000,- di nota/faktur penjualan. Dan selisih Rp. 50.000,- nanti akan dia simpan untuk dirinya sendiri ketika perusahaan atau instansi membayarkan Rp. 200.000,- sesuai jumlah harga di nota tersebut. Bahkan kadang pembeli meminta kenaikan harga sampai $100 \%$ dari harga jual.

Kedua, menulis nota/faktur sendiri. Cara yang kedua adalah pembeli menulis nota/faktur sendiri. Tentu harga yang dituliskan juga sesuai keinginannya sendiri. Untuk melakukan hal ini, pembeli biasanya meminta nota/faktur kosong dari si penjual. Pembeli hanya meminta stempel atau tanda tangan si penjual. Lalu pembeli akan menuliskan sendiri harga barang sesuai keinginannya. Jika ia ingin mendapatkan selisih yang banyak, ia akan menuliskan harga yang relatif tinggi.

Ketiga, mengubah nota/faktur. Selain menulis nota sendiri, praktek mark-up juga dapat dilakukan dengan mengubah nota. Pembeli akan mencetak nota sendiri dengan membubuhi stempel perusahaan atau instansi fiktif. Nama dan alamat yang tertera di nota juga adalah fiktif dan tidak ada wujud badan usahanya.

Keempat, meminta nota/faktur lagi. Cara lain yang dapat digunakan dalam praktek mark-up adalah dengan meminta nota/faktur lagi. Pembeli dapat beralasan bahwa nota/faktur yang lama telah hilang. Pembeli meminta dibuatkan lagi dengan tanggal sekarang dengan alasan jikalau dibuatkan tanggal yang lalu, akan mengacaukan pembukuan. Padahal pembeli sudah menyerahkan nota yang sebelumnya. Uang yang akan dibayarkan oleh instansi berdasarkan nota baru ini untuk disimpan si pembeli sendiri.

Dari penjelasan di atas mengenai praktek mark-up yang sering terjadi, maka dapat disimpulkan bahwa mark-up termasuk dalam kategori tindakan korupsi. Dalam arti luas, korupsi mencakup praktek penyalahgunaan kekuasaan dan pengaruh. Bentuk korupsi yang

24 “Post Tagged MARK - UP - Prof. Dr. Thohir Luth, MA," accessed November 16, 2020, http://athohirluth.lecture.ub.ac.id/tag/mark-up/. 
paling umum adalah "nilep dana" seperti mencuri (menilep) uang kas, mark-up dana proyek, dan sebagainya.

\section{Praktek Mark-up dalam Perspektif Etika Bisnis Kristen}

Pada bagian sebelumnya penulis sudah memaparkan deskripsi etika Kristen dan markup. Dengan demikian etika Kristen harus diterapkan oleh orang percaya di dalam dunia bisnis. Etika Kristen berlandaskan Alkitab sebagai dasar kebenarannya. Oleh sebab itu, untuk melihat mark-up dari perspektif etika Kristen harus dipaparkan terlebih dahulu pandangan Alkitab tentang mark-up tersebut. Alkitab tidak menuliskan secara langsung tentang korupsi, namun Alkitab berisi ajaran yang menentang tindak korupsi.

Pada waktu Yohanes pembaptis mengajarkan pertobatan di sungai Yordan, lalu datang pemungut-pemungut cukai untuk dibaptis dan mereka bertanya: "Guru, apakah yang harus kami perbuat?” Lalu Yohanes menjawab: “Jangan menagih lebih banyak dari pada yang telah ditentukan bagimu" (Luk. 3:12-13). Yohanes menegaskan bahwa Tuhan melarang pemungutpemungut cukai menagih pajak melebihi yang seharusnya meskipun mereka diizinkan oleh pemerintah melakukannya. Paulus juga menyingkapkan bahwa "cinta uang" adalah motivasi di balik keinginan untuk menjadi kaya dengan menghalalkan segala cara, termasuk melalui praktek mark-up. Paulus menuliskan:

"Tetapi mereka yang ingin kaya terjatuh ke dalam pencobaan, ke dalam jerat dan ke dalam berbagai-bagai nafsu yang hampa dan yang mencelakakan, yang menenggelamkan manusia ke dalam keruntuhan dan kebinasaan. Karena akar segala kejahatan ialah cinta uang. Sebab oleh memburu uanglah beberapa orang telah menyimpang dari iman dan menyiksa dirinya dengan berbagai-bagai duka" (1 Tim. 6:9-10).

Istilah "kaya" dalam bahasa Yunani adalah "plousios" yang berarti "kaya akan harta atau materi", merupakan lawan dari kata Yunani "ptookhis" yang berarti "meminta-minta, mengemis atau miskin secara materi". Keinginan untuk menjadi kaya telah menyebabkan banyak orang terjatuh ke dalam pencobaan dan jerat, bahkan kebinasaan (Bdk. 1 Tim. 6:9). Paulus mengatakan bahwa beberapa orang karena memburu uang telah disesatkan dari ajaran yang benar yang diimani. Segala cara dihalalkan untuk mendapatkan uang dan atau meraup keuntungan besar, termasuk dengan cara menipu. Kata "hamba uang" ini juga digunakan dalam Lukas 16:14 dan 2 Timotius 3:2 yaitu "philarguroi" yang lebih tepat diterjemahkan dengan "yang mencintai uang". Alkitab jelas melarang orang percaya untuk melakukan penipuan dalam hal apapun juga. 
Menurut Malcolm Brownlee, ada tiga jalan dalam etika Kristen yaitu: etika akibat, etika kewajiban, dan etika tanggung jawab. ${ }^{25}$ Penulis akan menggunakan ketiga jalan dalam etika Kristen tersebut untuk menganalisis praktek mark-up dari perspektif etika Kristen.

Pertama, etika akibat. Menurut penganut etika akibat, kehendak Tuhan dinyatakan dalam maksud-Nya, rencana-Nya, dan tujuan-Nya. ${ }^{26}$ Menurut etika akibat, suatu tindakan dianggap benar apabila perbuatan tersebut memberikan hasil baik yang lebih besar dibandingkan hasil buruk. Ditinjau dari etika akibat, praktek mark-up jelas hanya mengakibatkan hasil yang buruk, yaitu merugikan pihak lain dan menanamkan sifat egois dalam diri pelaku.

Kedua, etika kewajiban. Berdasarkan etika kewajiban, kehendak Tuhan dinyatakan dalam hukum-hukum atau perintah-perintah-Nya. Artinya, suatu perbuatan dikatakan salah jika bertentangan dengan hukum-hukum Allah. Jadi, jika dilihat dari etika kewajiban, praktek mark-up adalah perbuatan yang salah karena bertentangan dengan hukum Allah, yaitu jangan mencuri (Kel. 20:15).

Ketiga, etika tanggung jawab. Terakhir, menurut pandangan etika tanggung jawab, kehendak Tuhan dinyatakan dalam perbuatan-Nya atau kegiatan-Nya. Suatu perbuatan dianggap baik kalau sesuai dengan pekerjaan Allah. Dengan demikian, jika dilihat dari etika tanggung jawab, praktek mark-up adalah perbuatan yang salah atau buruk karena hal itu jelas tidak sesuai dengan pekerjaan Allah. Pekerjaan Allah adalah mendatangkan kebaikan bagi mereka yang mengasihi Dia (Rm. 8:28). Pekerjaan Allah tidak mungkin berlawanan dengan kekudusan Allah (1 Pet. 1:16).

Praktek penggelembungan dana dalam bisnis sangat bertentangan dengan spiritualitas Kristen yang diajarkan oleh Tuhan Yesus untuk mengasihi Allah dan sesama (Mat. 22:3740). ${ }^{27}$ Seorang yang mengasihi Allah akan menunjukkannya dalam tindakan melakukan kehendak Allah dalam seluruh aspek hidupnya. Dia tidak akan tertarik untuk melakukan halhal yang tidak sesuai dengan nilai-nilai firman Tuhan. Sebagaimana yang penulis paparkan di atas, praktek penggelembungan dana adalah tindakan penipuan atau kebohongan untuk memuaskan keinginan diri sendiri. Keinginan diri sendiri tersebut tentunya berorientasi dengan keinginan daging. Alkitab mengajarkan bahwa barangsiapa yang menjadikan dirinya sahabat dunia (hidup dengan prinsip dunia), maka dia menjadikan dirinya musuh Allah (Yak. 4:4). Selain itu, orang percaya yang mengasihi sesama juga tidak akan melakukan perbuatan

${ }^{25}$ Malcolm Brownlee, Pengambilan Keputusan Etis Dan Faktor-Faktor Di Dalamnya (Jakarta: BPK Gunung Mulia, 2011), 30.

${ }^{26}$ Ibid.

${ }^{27}$ Aprianto Kuddy, "The Power Of Spirituality: Menyanding Nilai-Nilai Ketuhanan Dalam Penerapan Etika Bisnis (Pendekatan Perspektif Kristen Tentang Aspek Kepemimpinan, Sumber Daya Karyawan, Kompetitor Dan Keseimbangan Alam),"Jumabis 1, no. 2 (2017): 48. 
yang merugikan sesama demi kepuasan atau keuntungan dirinya sendiri, termasuk dalam pekerjaan atau bisnis. Oleh sebab itu, etika bisnis Kristen menolak sama sekali praktek penggelembungan dana berdasarkan spiritualitas mengasihi Allah dan sesama.

\section{Implikasi Bagi Pebisnis Kristen}

Allah memang menginginkan orang percaya hidup dalam berkat-Nya, tetapi bukan keinginan untuk menjadi kaya dengan melegalkan segala cara. Ia benar-benar menginginkan kehidupan umat-Nya berhasil menurut kehendak-Nya (Yos. 1:8). Glen H. Stassen dan David P. Gushee mengatakan bahwa apabila orang Kristen benar-benar mengarahkan hati dan mata kepada kehendak Allah, dia akan menikmati kemerdekaan yang melepaskan dia dari keserakahan, nafsu untuk menumpuk harta, dan kekuatiran yang sia-sia. ${ }^{28}$ Setidaknya ada tiga implikasi bagi pebisnis Kristen untuk menjauhi praktek mark-up, yaitu:

\section{Bisnis Untuk Memuliakan Tuhan}

Bisnis Kristen dilakukan untuk kemuliaan Allah semata. ${ }^{29}$ Bisnis merupakan bagian dari pekerjaan manusia yang dianugerahkan oleh Allah. Alkitab memberikan pengajaran kepada orang percaya bahwa bekerja adalah kehendak Allah. ${ }^{30}$ Pekerjaan yang dilakukan oleh manusia bukan akibat kejatuhan Adam dan Hawa sebab Adam sudah diberikan mandat oleh Tuhan untuk berkuasa atas ikan-ikan di laut dan burung-burung di udara (Kej. 1:28). Mandat itu juga dipertegas dalam perintah Allah agar Adam memelihara dan mengusahakan taman Eden sebelum ia jatuh ke dalam dosa (Kej. 2:15). Jadi, bekerja merupakan panggilan Allah bagi semua manusia, bukan sebagai kutukan akibat dosa. ${ }^{31}$

Seorang pebisnis Kristen harus berpedoman pada Alkitab dalam prakteknya. Dia harus memancarkan terang yang ada pada dirinya dalam segala perilaku bisnis yang dilakukannya meskipun orang-orang di sekitar hidup dalam kegelapan. Artinya, kualitas seorang pebisnis Kristen sangat berbeda dengan pebisnis lainnya. Kualitas yang harus ditunjukkan oleh seorang pebisnis Kristen adalah kejujuran. Amsal 3:32 berkata, "karena orang yang sesat adalah kekejian bagi Tuhan, tetapi dengan orang jujur Ia bergaul erat.” Pada bagian lain, firman Tuhan berkata, "Orang yang jujur dilepaskan oleh kebenarannya, tetapi pengkhianat tertangkap oleh hawa nafsunya (Ams. 11:6).” Prinsip inilah yang menjadi inti hidup orang percaya yang menjadi garam dan terang di tengah dunia yang jahat ini, termasuk bisnis.

\footnotetext{
${ }^{28}$ Glen H. Stassen and David P. Gushee, Etika Kerajaan: Mengikut Yesus Dalam Konteks Masa Kini (Surabaya: Momentum, 2008), 540.

${ }^{29}$ Latupeirissa, 15.

${ }^{30}$ Bambangan, 136.

${ }^{31}$ Ibid.
} 
Hidup para pebisnis Kristen harus benar-benar berbeda dengan dunia ini. Pengusaha Kristen tidak boleh mengikuti cara-cara dunia yang penuh kecurangan dan penipuan, baik di dalam penetapan harga, ukuran atau berat barang, kualitas barang/jasa, maupun promosi barang atau jasa. Yesus pernah berkata, "Demikianlah hendaknya terangmu bercahaya di depan orang, supaya mereka melihat perbuatanmu yang baik dan memuliakan Bapamu yang di sorga (Mat. 5:16)." Segala pekerjaan, profesi, dan bisnis/usaha harus dilakukan oleh orang percaya hanya untuk memuliakan Allah. ${ }^{32}$ Oleh sebab itu, motivasi sebagai pelaku bisnis Kristen adalah untuk memuliakan Allah dan melayani sesama. ${ }^{33}$

\section{Bisnis Didasari oleh Kasih}

Kasih menjadi landasan bagi segi-segi kehidupan semua orang percaya. Tuhan Yesus mengatakan, "Kasihilah sesamamu manusia seperti dirimu sendiri (Mat. 22:37).” Allah sendiri telah menunjukkan kasih-Nya yang besar kepada manusia dengan mengorbankan Anak-Nya, Yesus di kayu salib untuk menebus dosa manusia (Yoh. 3:16). Dalam etika bisnis Kristen, kewibawaan Tuhan Yesus Kristus harus diakui. ${ }^{34}$ Tuhan menciptakan manusia dalam dimensi relasi kasih kepada Tuhan, sesama, dan lingkungan. ${ }^{35}$ Dimensi kasih tersebut harus terpancar dalam bisnis orang percaya.

Kasih kepada Tuhan memiliki pengertian bahwa bisnis dilakukan sebagai respon panggilan Allah dalam diri seseorang dan melakukannya dengan penuh rasa kasih kepada Tuhan. Dengan kata lain, bisnis adalah melayani Allah di dunia kerja untuk kesejahteraan seluruh ciptaan-Nya. Kasih kepada sesama berarti bisnis dilakukan untuk menjadi berkat bagi orang lain, seperti menghargai rekan kerja, memenuhi hak-hak orang lain, dan memiliki kemurahan hati untuk menolong orang yang membutuhkan. ${ }^{36}$ Terakhir, kasih kepada lingkungan dapat tercermin dalam tindakan yang selalu menjaga kelestarian lingkungan dengan tidak mengeksploitasi lingkungan. Jadi, manusia adalah bagian integral dari ciptaan (lingkungan dan mahkluk lainnya), akan tetapi di lain sisi, ia diberikan kekuasaan oleh Allah sendiri untuk memelihara bumi. ${ }^{37}$ Dengan demikian, hubungan manusia dengan Tuhan, manusia dengan sesama, serta manusia dengan lingkungan harus dijalani secara seimbang oleh kasih kepada Allah.

\footnotetext{
${ }^{32}$ Sundoro Tanuwidjaja and I Putu Ayub Darmawan, "Bisnis Dalam Perspektif Iman Kristen," Thronos Jurnal Teologi Kristen 1, no. 2 (2020): 86-98, http://ojs.bmptkki.org/index.php/thronos/article/view/5/5.

${ }^{33}$ Paul L. Cuny, Rahasia Ekonaomi Kerajaan Allah (Yogyakarta: Andi Offset, 2012), 22.

${ }^{34}$ Bertens, Etika (Yogyakarta: Kanisius, 2013), 36.

${ }^{35}$ William Dyrness, Tema-Tema Dalam Teologi Perjanjian Lama (Malang: Gandum Mas, 2013), 69-73.

${ }^{36}$ Latupeirissa, 15.

${ }^{37}$ Kuddy, 46.
} 


\section{Bisnis Merupakan Sarana Berkat Tuhan}

Bisnis merupakan salah satu sarana berkat Tuhan bagi orang percaya, bukan tujuan hidup orang percaya. Prinsip ini perlu dipahami oleh pebisnis Kristen agar tidak terjerat dalam keserakahan yang mendorong dia melakukan penipuan dalam perilaku bisnisnya. Tuhan tidak memberikan harta secara langsung kepada orang percaya, tetapi kekuatan untuk memperoleh harta kekayaan. Hal tersebut terlihat jelas dalam ayat ini,

"Tetapi haruslah engkau ingat kepada TUHAN, Allahmu, sebab Dialah yang memberikan kepadamu kekuatan untuk memperoleh kekayaan, dengan maksud meneguhkan perjanjian yang diikrarkan-Nya dengan sumpah kepada nenek moyangmu, seperti sekarang ini" (Ul. 8:18).

Nabi Yeremia menyampaikan firman Allah kepada orang Israel, "Sebab Aku ini mengetahui rancangan-rancangan apa yang ada pada-Ku mengenai kamu, demikianlah firman TUHAN, yaitu rancangan damai sejahtera dan bukan rancangan kecelakaan, untuk memberikan kepadamu hari depan yang penuh harapan" (Yer. 29:11). Tetaplah percaya kepada Tuhan dan lakukanlah yang baik (ayat 3-6); jangan iri hati kepada orang yang berhasil tetapi melakukan kejahatan (ayat 1, 7, 8); orang-orang yang melakukan kejahatan cepat atau lambat akan dihukum (ayat 2, 9-11).

Ringkasnya, karena Tuhan tidak dapat disuap (Ul. 10:17) dan Ia melarang suap dan penipuan (Kel. 23:8; Ul. 16:19), maka Ia tidak akan tinggal diam ketika orang-orang melakukan praktik suap/penipuan. Karena itu, orang yang melanggar kekudusan Tuhan dengan melakukan penipuan berupa mark-up, tidak akan pernah menikmatinya dengan aman dan cepat atau lambat ia akan dihukum oleh Tuhan.

\section{KESIMPULAN}

Berdasarkan pembahasan di atas, dapat disimpulkan bahwa mark-up adalah tindakan penipuan yang ditentang oleh Alkitab. Mark-up tergolong dengan tindak korupsi. Oleh sebab itu, iman Kristen tidak dapar menerima praktek mark-up dengan alasan apapun, karena Allah sendiri tidak menyukainya dan melarang umat-Nya melakukan penipuan tersebut. Dari pandangan etika Kristen (etika akibat, etika kewajiban, dan etika tanggung jawab), praktek mark-up adalah salah dan tidak sesuai dengan iman Kristen dengan alasan atau motif apapun. Oleh sebab itu, seorang Kristen harus benar-benar berani menolak untuk melakukan mark-up dengan alasan dan tujuan apapun itu. Bahkan orang percaya harus berani menegur/menasehati apabila ada saudara seiman yang melakukan praktek mark-up dengan lemah lembut (Ibr. 6:1). Dengan mau taat terhadap hal yang kecil ini, maka Tuhan akan melimpahkan berkat-Nya bagi mereka yang taat dan setia terhadap tujuan, hukum, dan perbuatan-Nya. 


\section{REKOMENDASI}

Pertama, bagi orang percaya secara umum. Penulis memberi rekomendasi agar orang percaya mempelajari firman Tuhan secara aktif agar dapat mengaplikasikannya dalam seluruh aspek hidupnya, termasuk bisnis sehingga menjadi berkat bagi orang lain. Selain itu, setiap orang percaya perlu memiliki seorang pembina atau mentor yang dapat membimbing dan mengarahkannya. Kedua, bagi pebisnis Kristen. Pebisnis Kristen sebaiknya memiliki komunitas sesama pebisnis supaya saling menguatkan satu dengan yang lain. Komunitas akan membantunya untuk kuat menghadapi godaan untuk berbuat curang atau tidak jujur dalam bisnis. Selain itu, para pebisnis Kristen juga perlu mengikuti seminar bisnis Kristen yang diadakan oleh gereja atau organisasi Kristen lainnya.

\section{DAFTAR PUSTAKA}

Bambangan, Malik. "Perspektif Teologis Terhadap Etika Bisnis Kristen.” Jurnal Luxnos 5, no. 2 (2019): 135-146.

Bertens. Etika. Yogyakarta: Kanisius, 2013.

Brownlee, Malcolm. Pengambilan Keputusan Etis Dan Faktor-Faktor Di Dalamnya. Jakarta: BPK Gunung Mulia, 2011.

Burkett, Larry. Kunci Sukses Bisnis Menurut Alkitab. Yogyakarta: Andi Offset, 1997.

Cuny, Paul L. Rahasia Ekonomi Kerajaan Allah. Yogyakarta: Andi Offset, 2012.

Dyrness, William. Tema-Tema Dalam Teologi Perjanjian Lama. Malang: Gandum Mas, 2013.

Geisler, Norman L. Etika Kristen: Pilihan Dan Isu Kontemporer. Malang: Literatur SAAT, 2010.

Hill, Alexander. Bisnis Yang Benar. Bandung: Kalam Hidup, 2001.

Ingels, Jack. Ornamental Horticulture: Science, Operations, and Management. Boston: Cengange Learning, 2009.

Keraf, A. Sonny. Etika Bisnis. Yogyakarta: Kanisius, 2000.

Kuddy, Aprianto. "The Power Of Spirituality: Menyanding Nilai-Nilai Ketuhanan Dalam Penerapan Etika Bisnis (Pendekatan Perspektif Kristen Tentang Aspek Kepemimpinan, Sumber Daya Karyawan, Kompetitor Dan Keseimbangan Alam).” Jumabis 1, no. 2 (2017): 48-55.

Latupeirissa, Jacky. "Etika Bisnis Ditinjau Dari Perspektif Alkitab.” PASCA : Jurnal Teologi dan Pendidikan Agama Kristen 15, no. 1 (2019): 8-15.

Ronda, Daniel. Leadership Wisdom. Bandung: Kalam Hidup, 2011.

Sanjaya, I Kadek Edy, I Nyoman Gede Sugiartha, and Ida Ayu Putu Widiati. "Pertanggungjawaban Pidana Pelaku Tindak Pidana Korupsi Dana Hibah Pengadaan Bibit Sapi (Studi Putusan Nomor 1/PID.SUS-TPK/2019/PN DPS)." Jurnal Preferensi Hukum 1, no. 1 (2020): 39-45.

Stassen, Glen H., and David P. Gushee. Etika Kerajaan: Mengikut Yesus Dalam Konteks Masa Kini. Surabaya: Momentum, 2008.

Swastha, Basu. Azas-Azas Marketing. Yogyakarta: Liberty, 2002.

Tanuwidjaja, Sundoro, and I Putu Ayub Darmawan. "Bisnis Dalam Perspektif Iman Kristen." Thronos Jurnal Teologi Kristen 1, no. 2 (2020): 86-98. http://ojs.bmptkki.org/index.php/thronos/article/view/5/5.

Teichman, Jenny. Etika Sosial. Yogyakarta: Kanisius, 2003.

Verkuyl, J. Etika Kristen Bagian Umum. Jakarta: BPK Gunung Mulia, 2009.

Wijaya, Hengki. "Metode Penelitian Pendidikan Teologi” (2013).

"Ada Penggelembungan Dana, BEI Akan Panggil Direksi AISA." Accessed November 16, 
2020. https://www.cnbcindonesia.com/market/20190327124001-17-63171/adapenggelembungan-dana-bei-akan-panggil-direksi-aisa.

"Apa Itu Mark up? Pengertian Mark up Dan Definisinya Dalam Kamus Ekonomi \& Bisnis." Accessed November 16, 2020. https://glosarium.org/arti-mark-up-di-ekonomi/.

"Direktorat Jenderal Anggaran." Accessed November 16, 2020. http://anggaran.kemenkeu.go.id/in/post/penggelembungan-anggaran-modus-latenkorupsi.

"Hasil Pencarian - KBBI Daring." Accessed January 29, 2021. https://kbbi.kemdikbud.go.id/entri/bisnis.

"ICW: Mark Up Dan Penyalahgunaan Anggaran Modus Korupsi Paling Banyak Di 2018." Accessed November 16, 2020. https://nasional.kompas.com/read/2019/02/08/11491331/icw-mark-up-danpenyalahgunaan-anggaran-modus-korupsi-paling-banyak-di-2018.

“Korupsi Pengadaan Barang Terbanyak, Mark Up.” Accessed November 16, 2020. https://www.viva.co.id/korupsi/110936-korupsi-pengadaan-barang-terbanyak-mark-up.

"Post Tagged MARK - UP - Prof. Dr. Thohir Luth, MA.” Accessed November 16, 2020. http://athohirluth.lecture.ub.ac.id/tag/mark-up/. 